\title{
Children without Childhood - Proletarianization of Children and Its Implications
}

\author{
Mariam John Meynert \\ Independent Educational/Childhood Researcher, Sweden
}

Copyright $\bigcirc 2017$ by authors, all rights reserved. Authors agree that this article remains permanently open access under the terms of the Creative Commons Attribution License 4.0 International License

\begin{abstract}
Ariès's famous book Centuries of childhood (1962), has influenced the widely acknowledge view that the concept of childhood is a social and cultural construction. Cross-cultural and historical researches have asserted that the idea of childhood has varied across different cultures and epochs thus belying the universal conceptualizations of childhood. Hermeneutical readings of historical and sociological texts have encouraged me to construct the notion that there are children who live out their lives without childhood - both in the past and in the present. In addition to this I deconstruct the notion of "universal childhood" and make the following assertions: that in the medieval period childhood as we understand it today may not have existed; that childhood could be said to be a modern invention; that in the postmodern childhood is fast disappearing. I argue that in the wake of the Enlightenment and the Industrial Revolution, two contrasting trends emerged regarding children, viz. the notion of child centeredness (among the emerging middle classes), and increasing proletarianization of children (among the lower classes). The $20^{\text {th }}$ century has seen a reduction in child labour due to legislations regarding children, compulsory schooling and the Welfare state. Despite this, today there are millions of children living without childhood. In the $21^{\text {st }}$ century, there are one billion children still living in conditions of poverty resulting from neo-liberal policies and the unequal World order. I further argue that recovering childhood is insidiously connected as much with structural changes as economic ideologies and collective legislations.
\end{abstract}

Keywords Social-construction, Childhood, Child-centeredness, Child-labour

\section{Introduction}

It was in the 70 s that I first heard about the adage "Children without childhood" when I attended a NIPCCD (National Institute of Public Cooperation and Child Development) workshop in India. UNICEF had perhaps coined this term out of concern for millions of children working in sweat shops and household industries.

It was only in 2016 when I presented a paper in the Research Commission of the Sociology of Childhood (RC53) at the 3rd Mid-term ISA Forum of Sociology in Vienna that I looked into the literature, history, reality and ideas with regard to the concept "Children without Childhood". This article is a hermeneutical reading of historical and sociological texts and is a spin off from my Phil. Lic research at Lund University called: Conceptualizations of Childhood, Pedagogy and Educational Research in the Postmodern - A critical interpretation. [1]

At first it appeared to be a contradiction to assert the notion "Children without childhood", since as a rule we associate children with childhood. The term childhood being defined as the age span between infancy and adolescence. Having constructed that there is a period that is called childhood, and because there are cultural and economic conditions in which the period of childhood gets shortened, one could construct that some children have less childhood than others.

The body of the article discusses the following research questions: a) Is childhood a social construction? b) Was childhood non-existent in Medieval times? c) Is childhood a modern invention? d) How two contrasting trends child-centeredness and proletarianization of children emerged during the Industrial revolution? e) Reasons why children without childhood are persisting into the $21^{\text {st }}$ century? f) Is childhood disappearing in the postmodern age? g) Can childhood be recovered?

\section{Methodology}

\subsection{Methods and Material}

This article is an outcome of my hermeneutical readings of historical and sociological texts in order to construct the notion "Children without childhood" due to the proletarianization of children during the Industrial Revolution and the persistence of child labour today. 
Texts from Sociological websites and articles, ILO, World Bank, Amnesty International, books and sociological Journals touching the concept of "child labour", the "history of childhood", "childhood as social construction", "Convention on the rights of the child", "neo-liberal policies and persistence of poverty" were read and re-conceptualised in order to develop a red thread between the conceptualizations and the evolution of childhood over the different historical epochs. These reading have helped consolidate the argument that "children without childhood" is a consequence of the growth of Industrialization at the onset of the modern era and persists into the present times, despite International efforts to recover childhood, due to neo-liberal policies and the unequal world order.

\subsection{Meaning of Hermeneutics}

Hermeneutics is the theory and methodology of interpretation and meaning making (semiotics) of texts - both verbal and non-verbal. Hermeneutic human sciences study the objectivations of human cultural activity (e.g. texts) with a view to interpreting them, to finding out the intended or the expressed meaning, in order to establish a co-understanding, and in general to mediate traditions so that the historical dialogue of mankind may be continued and deepened.

Sociological hermeneutics stresses the critical importance of locating the meaning of text or an act within the context of the discourse or the world view from which it originates. This has inspired Heidegger's hermeneutical circle that simultaneously claims that understanding of the individual parts of the text is based on the understanding of the whole text; while the understanding of the whole text is dependent on the understanding of each individual part.

Kvale [2] asserts that the researcher is always operating within an ever widening circle of socially constructed truth claims which must be negotiated. The researcher positioning himself within this debate becomes a dimension of methodology. Interpreting a text correctly, then involves a "fusion of horizons" - a "community of interpretation" made up of scholars who decide what the community's view of truth will be. Each participant contributes his perspectives to this mix of interpretations.

I practice Critical hermeneutics (a partnership of hermeneutics with a critical approach) in this analysis. The notion of hermeneutic as a research approach has shifted in focus and understanding over different epochs. From a theory of interpretation, today hermeneutics provides the critical horizon for intriguing discussions. Critical hermeneutics takes the interpretative process of hermeneutics further and addresses issues of power and ideology and situates hermeneutic analysis in a wider socio-economic and historical setting. Critical hermeneutics adopts a dialectical and deconstructive approach. The hermeneutical circle (unlike the tautological circle of logic) in critical hermeneutics is the development of knowledge through dialectical analysis.

\section{Results, Analysis and Discussion}

The hermeneutic analysis of the text read are discussed below in a holistic style yet making visible the parts that build up the whole: that childhood is a social construction; that "children without childhood" have always existed - from medieval times to the present; that proletarianization of children emerged and consolidated within the lower classes during the Enlightenment period, the age of reason and the Industrial revolution, simultaneous to the emergent notion of child-centeredness within the growing middle classes; that in postmodern times childhood appears to be disappearing; and finally despite international efforts to recover childhood, neoliberal policies and unequal world order have resulted in the persistence of children living in conditions of distress and poverty.

\subsection{Childhood: A Social Construction}

I begin this article by developing an argument that childhood can be understood as social and cultural constructions. Social construction is a term which means that understandings of childhood are not the same everywhere and that while all societies acknowledge that children are different from adults, how they differ and what expectations are placed on them, change according to the society and period in which they live.

Social historians concede that the concept of childhood as we understand it today emerged during the 17th and 18th centuries and was a result of the developing individualism, sentimentalism, the nuclear family structure and the educational theories of modernist philosophers. Cunningham [4] notes that before this period children were often seen as miniature adults or incomplete versions of adults.

Social constructionism is a theory that emphasizes that truth, reality and knowledge is socially embedded. A socially constructed truth and reality is one that is seen as an ongoing dynamic process, reproduced by people acting on their interpretation and their knowledge of them.

Childhood, child rearing and care-giving are areas of human development which are taken for granted within a single culture. Lancy [5] documents that researches in cross-cultural perspectives on childhood reveal that approaches to childhood and children vary across countries and peoples around the world. Despite the fact that in these cultures children go through same stages of physical development, these stages are understood and constructed differently in different cultures. It is important here to stress that cross cultural and ethnographic accounts have weakened the stronghold of the western middle class notions of childhood, child rearing and child development.

There are some ontological given and near universal agreement that there are fundamental differences between adults and children. Children are seen as physically and psychologically immature compared to adults and dependent on adults for their biological and emotional needs. Despite general agreement about differences between adults and 
childhood, there are no fixed ideas about what childhood is, and it differs across time, places and cultures. Every society gives these biological differences separate meanings.

\subsection{Definition of Childhood}

For the purpose of the thesis of this article that, "children without childhood" have emerged and consolidated during the industrial revolution and persist into the $21^{\text {st }}$ century, it is necessary to define what is meant by the term childhood. I invoke CRC's (Convention on the rights of the Child) definition of child as: a person below the age of 18 . Childhood is a separate space from adulthood, where children have a right to survival and healthy development with adequate standard of living and shelter, health care, balanced diet, access to schooling and safe play spaces. Childhood would then mean much more than just the space between birth and the attainment of adulthood. It would refer to the state and condition of a child's life - to the quality of those years. The term "children without childhood" would then express the state of children living in conditions below the quality of standard set for children by the CRC definition.

\subsection{The Structure of the Article}

In this article I intend to make two important conclusions: a) Childhood is seriously affected because of neo-liberal policies and the unequal World order; $b$ ) Children among the lower classes have always had shortened childhood - in the past and the present. In order to reach the above mentioned conclusions I proceed to make the following constructions about childhood that:

1) In the medieval times childhood as we know it today may not have existed.

2) Childhood can be understood to be a modern invention.

3) The Industrial Revolution has resulted in two starkly contrasting trends: child centeredness among the middle classes and proletarianization of children among the lower classes.

4) There is persistence of "children without childhood" in the $21^{\text {st }}$ century due to neoliberal policies and the unequal world order.

5) In postmodern times (or high modernity) childhood may be disappearing

6) Recovering childhood is possible only up to a point and is connected structural changes and economic equality.

\subsection{Childhood: Was it Non-existent in Premodern Times?}

Social historians have in recent years concerned themselves with questions about childhood and asked whether our current ideas about childhood are inventions of modernity. Historians like Philippe Ariés in Centuries of childhood [6] and Lloyd deMause [7] in The history of childhood have asserted that in premodern times, current ideas if childhood did not exist. According to this view the idea of childhood was invented between the 16th and 20th century. Prior to this, children were not seen as essentially different from adults like they are known to be today.

Ariés uses the following evidence to support his views: children were expected to work at a much earlier age; the law often made no distinction between children and adults; works of art from the period often depicted children as small adults - they wore the same clothes and appeared to work and play together. Edward Shorter [8] argues that parental attitudes to children in the Middle-ages were very different from today. High infant mortality rates encouraged indifference and neglect, especially towards infants. Parents often neglected to give new born babies names - referring to them as 'it' and it was not unusual to give a new baby a name of a dead sibling. DeMause [9] portrayed the classical childhood as a period where children were frequently killed or abandoned, through medieval indifference and where wet-nursing and the 'farming out' of children were common. Ariès [10] and other historians associated with his view have tended to see childhood in medieval times as having less significance to their parents. Fathers especially were less emotionally involved with children and were less affected by the impact of children's illness or death. Ariés argues that it is only from the 13th century onwards that modern notions of childhood - the idea that childhood is a distinct phase of life from adulthood begins to emerge. Ariés further argues that childhood as we understand it today is relatively recent. Although a number of elements of Ariès's position are now contended, his work generated a great deal of interest in the history of childhood. He argued that childhood was a social construction and that historians should take children and their lives seriously. This has resulted in an increasing number of historians adopting children's perspectives in their studies of childhood, allowing the voices of children to be heard in historical accounts. Meynert [11] documents studies of Barbara A. Hanawalt's [12] Growing up in medieval London (1993) and West's [13] Children on the plains (1992) as examples of such accounts.

A number of other historians such as Alston [14], Nasaw [15], Pollock [16], Shahar [17], and Wiggins [18] have criticized the grand-stage theorists such as deMause [19], drawing upon impressive historical evidence to support their critique. The best known of these critics is Linda Pollock [20] who in her book Forgotten Children (1983), challenges the historical conceptions of childhood in the works of Ariès [21] and grand-stage theorists such as deMause [22]. Pollock undertook an analysis of 500 British and American diaries, autobiographies and related sources and found little support for Ariès thesis that there was a constant indifference to children and to deMause's contention of widespread mistreatment and abuse of children until the enlightenment period of the 18th and 19th centuries.

\subsection{Childhood: A Modern Invention}

The academic camps that oppose and share Ariès's views, share an important perspective that argues that modernity brought in the shift about the way children were perceived. It brought about a shift from indifference or neutrality to high 
valuation. Clarke [23] argues that the 20th century brought in a child centeredness not found in previous epochs. Modern notion of childhood was forged during the Enlightenment or The Age of Reason which spanned from about the 1620s to about the 1780 s that challenged the traditional, and irrational ideologies of the middle Ages. Fass [24] asserts that over the 17th and 18th centuries, there was a sharp turn toward scientific reason and advanced philosophical thought. Children were a big focal point for the many new forms of societal change in this age of reason.

This view resonates Ariès [25] who draws on the "history of feelings" and connects the development of sentimental emotions and the modern world view that led to a transition in people's ideas about childhood. In other words the development of sentiments and feelings in the seventeenth century laid the foundation for modern views of what childhood is. The modern world was characterized by a separate isolated family unit which was centered on the needs of the child. According to Lawrence Stone [26] only with the growth of the middle classes and the stress on individualism which came with industrialization did a child-centered view emerge, gradually filtering down from the middle class to the rest of society.

Fleer, et al [27] notes that it was not until early 1900s that childhood was conceptualized as universal - when the middle class communities determined an identity for children, thus constructing a "modern view of childhood". Hendricks [28] states that childhood became constructed and reconstructed into age-periods and took on a public identity. Construction of "childhood" evolved over time from Naturalism, Romanticism and Evangelicalism. Wage-earning labour got transformed into a period of "childhood", a "child study" movement was founded, "children of the nation" was conceived as a public phrase, and finally "children of the welfare state" was invented. According to Hendricks, modern childhood was legislatively, socially, medically, psychologically, educationally and politically institutionalized. Kincheloe [29] argues that along with the institutionalization of childhood came a way for describing children in universal terms.

\subsection{Development of the Ideology of Child-Centeredness}

The middle-class family model of ideology spread from the 17th century onwards and is associated with newly emerging commercial classes in Western Europe and is based upon the idea of the self-contained patriarchal family with father as head of the family. Clarke [30] documents that the central purpose of the family was the upbringing of children. The key focus was education of children - in order to 'school' the child in correct behavior enforced by discipline.

From around the middle of the 18th century, many people in Britain began to think about childhood in new ways. In the mid-18th century, childhood began to be viewed in a positive light, as a state of freedom and innocence. Central to the change in how childhood was understood was the work of the philosopher, Jean-Jacques Rousseau [31], whose Émile, or On Education (1762) not only rejects the doctrine of the "Original Sin", but maintains that children are innately innocent, only becoming corrupted through experience of the world.

Modern educational philosophers such as John Locke (of the Enlightenment period) and Jean Jacques Rousseau (of the Romantic period)) emphasized benign child-centeredness. Children were seen as innocent, close to nature, uncorrupted and pure. Both emphasized the importance of shaping young minds early. This view was largely confined to the enlightened aristocracy and the new middle classes. For the great mass of the population of Western European countries like Britain and France, children's lives were characterized by poverty, hard labour and exploitation. There was a contradiction between a romantic idealized view of childhood rooted in eighteenth-century Enlightenment and the brutal reality of most children's lives. [32].

Fass [33] observes that the modern perspective of children as sexually innocent, economically dependent, and emotionally fragile and whose lives are supposed to be dominated by play, school and family nurture, provides a very limited view of children's lives in the modern Western past. While some children did experience this kind of childhood, for the vast majority, it is quite literally only in the twentieth century that these have been enforced as both preferred and dominant.

\subsection{Proletarianization of Children in the 19th Century}

While the newly emergent middle classes were developing a child-centered ideology of the family, the impact of industrialization on the rest of the population had been to intensify the exploitation of many children's lives. For many children in the early 19th century things grew worse. The industrial revolution created a huge demand for female and child labor. Children's work was largely seasonal so they did have some time to play.

Child labour had formed an intrinsic part of pre-industrial economies and children always worked in farming or in cottage crafts. The work of children was needed for their survival and the survival of their families. Since there was low productivity and short life expectancy, children were kept from participating in work that would harm them and their group in the long run. There was little need for children to attend school and knowledge was passed down through direct mentoring or apprenticing by adults. One can see parellels in present day rural and pre-industrial societies where the concept of childhood differs from that which is known in the modern developed countries. Diamond [34] notes that children in these societies often begin to actively participate in activities such as child rearing, hunting and farming as soon as they become competent. In many societies, children as young as 13 are seen as adults and engage in the same activities as adults. 
The emergence of the factory system introduced the idea of going out to work. For the first time the workplace was separate from the family and children who had to work in mines and cotton mills had to travel to their workplaces. Their working day were often longer than 14 hours. Child labour was not just a side effect of industrialization. Child workers were often preferred to men or women because of their flexibility, their docility and their low cost. [35]

Child labour refers to the employment of children in any work that deprives children of their childhood and interferes with their ability to attend regular school. [36] The work is usually mentally, physically, socially or morally dangerous and harmful. Child workers were economically essential to their families and made a major contribution to household incomes. The massive movements of population which preceded and accompanied the industrial revolution had led to a growth in the numbers of abandoned children. By the end of the nineteenth century, the lives of most children were still dominated by poverty, ignorance and illness. These conditions have triggered off a number of academics to coin the phrase "Children without childhood".

Even as the idealization of childhood spread among the new middle class that emerged during the industrial revolution, the exploitation of children of the lower classes stood out as a sharp contrast. It was this contradiction that started the movement to limit and eventually to abolish child labour. [37] In the early 19th century the British parliament passed laws to curtail child labour. Throughout the second half of the 19th century, child labour began to decline in industrialized societies due to regulations and economic factors. There were a series of Factory Acts that limited working hours and set minimum wages and age.

The idea was spreading that childhood was a period of life in need of protection. It became appropriate for the state to intervene and this laid the foundation for the 20th century Welfare State. As technology improved and proliferated, there was a greater need for educated employees. This saw an increase in schooling, with the eventual introduction of compulsory schooling. The idea of childhood as a special phase was even more strongly reinforced by the development of compulsory state schooling. Hendricks [38] observes that as the century progressed it was the need to attend school rather than the illegality of employment which ended the excesses of child labour. By the end of the nineteenth century, while the lives of most children were still dominated by poverty, ignorance and illness, the idea of child-centeredness as a key focus for policy development had firmly taken root, paving the way for the twentieth century - described by many commentators as 'the century of the child'.

\subsection{Twentieth Century - The Century of the Child}

Childhood in the twentieth century is regarded as being separated from adulthood. According to Sandin [39] the twentieth century bears the stamp of increased professionalization in the care of children and has ended up in the border zone between public and private, even if it has not shifted entirely into the public sphere. The development in the twentieth century has sometimes been described as the colonization of the family by the state and public.

The twentieth century family is seen as child-centered and focused on the welfare of the child in a way different from that in previous centuries. Due to economic factors and women's education and employment there was both an evolutionary as well as a deliberate limitation of family size which led to increased attention on the individual child. Compulsory schooling and decline in child labour has resulted in a change from perceiving children in terms of instrumental values and replacing it by their expressive value. James \& Prout [40] documents that children have become relatively worthless economically to their parents but priceless in terms of their psychological worth. Priorities in the social and cultural life of Anglo-European and American countries have dominated the construction of childhood where norms and values are associated with the ideal of a safe, happy, protected childhood.

Ariès [41] argues that it is only modern changes, particularly the development of schooling prescribed and provided by the state, which brings about the phase we call childhood, as we know it today. It is in the twentieth century that the welfare of children became not just a family responsibility. Children were seen increasingly as the responsibility of the state, which intervenes in their education, their health, their diet and their upbringing in ways designed to improve the national well-being by developing its future citizens.

A further development is the idea of the child and their development as a proper subject for scientific study. The growth of psychology as a discipline is closely tied to the role it played in the increased surveillance and control of childhood. In the late twentieth century, primarily because of the spread of the middle-class ideology of the child-centered family, the development of compulsory universal schooling and the preoccupation of policy makers and welfare institutions with the interests of the child, there come into existence a new idea of childhood in the affluent West. The United Nations brought children to the fore front of international politics when the General Assembly declared 1979 the Year of the Child, followed in 1989, by the adoption of the UN convention on the rights of the child (CRC). CRC was a by-product of international commitments to human rights, but its history lies in the complex and contradictory developments of the twentieth century, when elevated expectations regarding the welfare of children confronted the realities of war

\subsection{Persistence of "Children without Childhood" into the 20th and 21st Century}

Despite the interventions by International Organizations and Nation States, not all children have come into the fold of institutions with interest in child welfare. While sharp reductions in child labour in industrial nations may have been seen due to activism and economic and social progress, 
some of these problems have been exported to developing countries which already had their own child labour problems.

The global unequal economic order has resulted in international inequality and world poverty. Freedman [42] documents that well into the 20th and 21 st centuries, children's exploitation continued to exist. In the early 20th century there were thousands of boys under the age of 16 years employed in glass making industries exposed to intense heat causing eye problem, lung diseases, heat exhaustion, cuts and burns. Factories and mines as well as home-based industries still used child labour. When labour in the factory got regulated by Government, work moved out of factories into urban homes. Families and women preferred this because they could generate income while attending to house hold duties. Poor families encouraged their children into these income generating home enterprises which resulted in children between 5 and 14 working besides their parents.

Khakshour, et al [43] documents that according to World Bank data, in 2003 incidence of child labour is still common in many parts of the world. 85 million children work in dangerous conditions. Estimates for child labour varies between 250 and 304 million. $60 \%$ of the child labour is involved in farming, dairy, fisheries and forestry. While two out of three children work in unpaid family work, $25 \%$ of child labourers are involved in vending, carrying loads, recycling trash and as domestic servants. The rest of the $15 \%$ work in assembly and manufacturing in informal economy. $70 \%$ of child labour is in rural areas and $26 \%$ in informal urban sectors.

About 2 million children in developing countries die every year from a lack of access to safe drinking water and adequate hygiene and sanitation facilities. Despite progress in school enrolment in many parts of the world, the number of children aged 6 to 11 who are out of school has increased since 2011. Nearly 250 million children live in countries and areas affected by armed conflict. Over 110 million primary school age children world-wide are not enrolled in school. $49 \%$ will never attend school. 500,000 children under 15 years of age died from AIDS in 1999, and 3, 8 million died since the beginning of the epidemic. 11 million children die each year from largely preventable causes. More than 33 million children suffer from vitamin A deficiency, placing them at risk of blindness and death from such common diseases as measles and diarrhea. An estimated 250 million children aged 5 to 14 are working around the world. Close to 2 million children have been killed in armed conflicts during the past decade. [44]

\subsection{Children without Childhood and Poverty - Structure or Agency?}

Poverty and its manifested deprivation in well-being leads to child proletarianization. Poverty results from groups of populations within nations being excluded from the possibility of accessing goods and services necessary for survival. Poverty involves low levels of health and education, poor access to clean water and sanitation, inadequate physical security, inability to be heard and insufficient capacity and opportunity to better life conditions.

According to Ravallion [45], there is global prevalence of poverty. In 2012 it was estimated that, given a poverty line of $\$ 1,25$ a day 1,2 billion people live in poverty. About $32,2 \%$ of these people live in sub-Saharan Africa, 13, 5\% in Asia. Given the current economic model, it is predicted that it will take at least 100 years to bring the world's poorest to a poverty line of 1, 25\$/day [46]. Extreme poverty is observed in all parts of the World including developing countries resulting in 1 billion of the world's children living in poverty. Haymes et al [47] have argued that neoliberal policies (manifestations of collective agency) promoted by global institutions such as IMF and World Bank are aggravating inequality and poverty.

Social structures hold implications for action, just as the action of humans create structural conditions that limit or free. Structural conditions leading to poverty in turn affects the agency of populations to get out of the viscous cycle of poverty. Social aspects of poverty is linked to conditions of scarcity and to aspects of distribution of resources and power in a society and recognizes that poverty may be a function of diminished "capabilities" of people to live the kinds of lives they value. In 1979 Townsend [48] in his book Poverty in the United Kingdom, asserts that poverty is not simply a lack of income but the shaping of the economic condition that prevent people from being full members of the society, reducing the ability of people to participate in society. $\mathrm{He}$ suggested that there was a critical point within income distribution below which participation of individuals collapse.

Structure and agency couple together to keep children in misery and drudgery. Cycle of poverty keep millions of children in hunger, misery, drudgery, illiteracy and abused especially in the developing countries. Today into the $21 \mathrm{st}$ century many children live adult lives, taking on inappropriate jobs for their ages in order to supplement family incomes, for their own survival and provide unpaid family labour. Children can be forced into submission and hence are attractive for employers. Certain activities like cotton growing is very labour intensive and there is a demand for cheap labour. In other types of work like a family business or farming, children might be pulled into work because education is not valued and work is considered more useful. In some countries children are expected to work by cultural tradition and as part of growing up.

The relatively low wages paid to children are often a reason for employers to prefer them to adults. Some children work unpaid as domestic servants just for food and lodging. Children are often more obedient, easier to control and can be intimidated. Moreover, children are unlikely to unionize. When children are dependent on their place of work for food, lodging and emotional support employers can force them into submission. In countries where it is acceptable for parents to beat their children, employers take advantage of 
the acceptance of corporal punishment by the informal sector and beat children into submission. I would like to add here that passivity of children located in conditions where childhood is shortened, should not be taken for granted. There is a large body of childhood researches that have emphasized children's capacity as experiencing subjects who are capable of autonomous action. [49]

\subsection{Inadequate Implementation of Laws}

More than 130 countries have signed an International convention saying that children may not work full-time before the age of 14 or 15 years. Laws are generally ignored. In some countries laws are vague and confusing and not enforced. Employers find loopholes to justify children working for them. In these countries due to inadequate registration of birth or lack of birth certificates, children's ages cannot be established. Without documentation children may be denied access to state services like education. Not attending school is a cause and effect of child-labour. In many countries education is not free and out of reach of the poor and the destitute.

ILO suggests that the cause of the pernicious existence of child labour is poverty. In impoverished households, $25 \%$ to $40 \%$ of the house hold incomes comes from children's work. Liberal and neo-liberal ideologies within international monetary organizations often ignore or gloss over the solutions to equalize world order. Structural inequalities between nations and within nations lay the foundation for persistent poverty thus keeping children in conditions of distress.

\subsection{The Postmodern Age - is Childhood Disappearing?}

Postman [50] in his book The disappearance of childhood, argues that childhood as we know is disappearing and that the distinction between adulthood and childhood is narrowing. Kathleen McDonnell, [51] in her book Honey, We Lost the Kids, stresses that the lines that used to distinguish between adulthood and childhood are growing blurred through television and internet/social media. Children are now able to access the "adult world", as a result childhood as we know is fast disappearing in the West. There is a growing similarity in the adult and children's clothing. There are cases where children are playing computer games that simulate mass murder, as well as commit adult crimes like murder and rape. There is also a growing emphasis on "Learners Voice" in education. Children are also increasingly being used on interview panels for new teachers. The UN rights of the child are giving them same rights as adults. Childhood that used to be a protected sphere where adult gatekeepers could control what and when children learned about the grown-up 'facts of life', is slowly disappearing.

Parents and children are becoming more equal. There is the phenomenon of "Kidults" where adults are increasingly becoming more like children. Kincheloe [52] argues that the traditional notions of childhood as a time of innocence and adult dependency have been challenged by children's access to corporate-produced popular culture. Kincheloe further notes that children turn their technology-enhanced isolation into a form of power, where they soon learn to know more than their parents about different corporate brands. Children are enjoying the power of generating their own discourse, and technological knowledge expertise - thus problematizing the traditional beliefs of "childhood" as innocent, cute or in need of protection.

David Elkind [53] shows in his book The Hurried Child: Growing up Too Fast Too Soon that the pressure isn't only coming from the mass media, but from adults themselves. Adults are participating in the sped-up pace of modern childhood. More and more parents are imposing adult standards of success and achievement on children, jumping on the early-learning bandwagon and pushing their kids to excel at earlier and earlier ages. Whole sectors of the economy have sprung up to exploit parents' fears that unless their kids get on the fast-track they'll end up losers in the high-tech competitive marketplace.

Postmodernism is the co-existence of several trends - high modernity, late modernity and fragmenting modern moments among others. The onset of the Information Age in the postmodern era is associated with digital revolution and has sped up the pace of childhood. There is a connection between the simultaneous disappearance of childhood within the privileged technologically aware classes in the North and the continued deprivation experienced by poor children in the South. Neoliberalism - the dominant economic ideology advocating free market approach to policymaking, privatization, public spending cuts, and deregulation, have increased poverty and inequality and posed an obstacle to the eradication of poverty since it contributes to the creation of scarcity and conceals how those mechanisms function, thereby disempowering the poor. Global inequalities have sharpened. 86 percent of the world's resources are consumed by the world's wealthiest 20 percent.

\subsection{Attempts to Recover Childhood}

Trapped in a cycle of disadvantage, children from the poorest households of the globe, are effectively pre-selected for heightened risks of disease, hunger, illiteracy and poverty based on factors entirely outside their control. They are nearly two times as likely to die before the age of 5 , and in many cases, more than twice as likely to be stunted as children from the richest households. They are also far less likely to complete school. Those who survive this precarious start find little opportunity to break free from their parents' poverty and to shape their own futures. Around the world, children make up nearly half of the almost 900 million people living under the poverty line. Their families struggle to afford the basic health-care and nutrition needed to provide them a strong start. These deprivations leave a 
lasting imprint. In 2014, nearly 160 million children were stunted. Many children work at dump sites, cut stones, work in small factories, car workshops or as a carrier in ports or on construction sites. Parents also send their children out to beg on the streets. Others work as prostitutes or domestic slaves. Today hundreds of children all over the world live on the streets, work in hazardous places, are abused on a daily basis and often do not have the most fundamental human rights.

It was to protect the rights of such children that the United Nations adopted a historic agreement in 1989: the Convention on the Rights of the Child (CRC).

In general, the Convention calls for:

- Freedom from violence, abuse, hazardous employment, exploitation, abduction or sale.

- Adequate nutrition.

- Free compulsory primary education.

- Adequate health care.

- Equal treatment regardless of gender, race or cultural background.

- The right to express opinions and freedom of thought in matters affecting them.

- Safe exposure/access to leisure, play, culture and art.

Three categories of children's rights are given below:

1) Provision - Children's right to adequate standard of living and shelter, health care, balanced diet, access to schooling, education and services, and to play and recreation.

2) Protection - Children's rights to protection from abuse, neglect, exploitation and discrimination. Right to safe play spaces and constructive child-rearing behaviour.

3) Participation - Children's rights to decision making, participate in communities, and have programs and services for themselves, including libraries, community programs. [54]

Meynert [55] documents that the CRC has led to Amnesty International advocating an end to juvenile incarceration without parole; an end to the recruitment of military use of children; abolishing the death penalty for those younger than 21 years of age; and raising awareness of human rights in the classroom. Human rights organization Watch has advocated an end to child labor and corporal punishment, promotion of juvenile justice and the social care of orphans and abandoned children as well as refugees and street children. Other issues affecting children's rights focus on the prevention of military use of children, sale of children, child prostitution and child pornography. Scholarly studies identify children's individual rights such as freedom of speech, freedom of thought, freedom from fear, freedom of choice, rights to make decisions and ownership over one's body.

\subsection{Challenges Ahead}

There appears a wide acceptance of the CRC that gives the misleading impression that it is neither challenging nor new. Yet the very idea that children are the holders of rights is far from universally recognized. Too many children are considered to be the property of adults, and are subjected to various forms of abuse and exploitation. The recognition that children have a right to a say in decisions affecting them, is not only disrespected on a regular basis, its very legitimacy is questioned by many. Nor can we claim that we live in a world where children's best interests are the primary consideration in all decisions affecting them. In fact, the contrary is evidenced by the way resources are allocated and the limited attention it gives to ensuring the best for children.

Like all powerful ideas, the CRC reflects a demand for deep and profound change in the way the world treats its children. That the world fails to respect the rights of its children - even to deny that children have rights - is clear in the alarming numbers of children who die of preventable causes, who do not attend school or attend a school that cannot offer them a decent education, who are left abandoned when their parents succumb to AIDS, or who are subjected to violence, exploitation and abuse against which they are unable to protect themselves. It cannot be claimed that the Convention has achieved what needs to be achieved. Rather, it has provided the world with an essential foundation for changing what needs to be changed.

\section{Conclusions}

Childhood as a social construction first acknowledged by Ariés in 1962 has widely been accepted by academics today. There is sufficient evidence to show that childhood as we know it today was constructed due to the Enlightenment, The Age of Reason and the Industrial Revolution. This has led to a development of a contrasting trend in the treatment of children viz. child-centeredness among the growing middle-class and the proletarianization of children among the lower-classes. Child labour has now been curtailed due to legislations regarding children working, compulsory schooling and the Welfare State.

Despite the privileges afforded to middle class children in the West, their typical childhood experience is no longer seen as an ideal model for other parts of the globe. Recent researches, reports and policy concerns suggest that on the one hand growing up in the West may be marked by the commercialization of childhood, hurried and even the disappearance of childhood, precociousness and a loss of innocence. On the other hand, growing up in poor areas in the East, West, North and South leads to hunger, poor health, abuse, militarization and loss of childhood. Efforts to recover childhood in the poverty ridden areas of the globe brought in the Convention on the Rights of the Child (CRC) in 1989, which became the first legally binding international convention to affirm human rights for all children. The treaty has inspired changes in laws to better protect children, altered the way international organizations see their work for children, and supported an agenda to better protect children in situations of armed conflict.

This has also led to a plethora of researches that recognize agency of children, ethnographies of children in distressed 
environments, growth of childhood agencies and recognition of child's rights to provision, protection and participation.

Following The Convention of the Rights of the Child (1989), globalization and systematic collection of statistics By ILO and World Bank, the world became aware that from a global perspective the child labour situation was not much better than it had been during the industrial revolution [56]. Large number of children were working long hours in factories and sheds that were poorly lit, squalid and a hazard to health. ILO [57] estimated that there are 186 million child labourers, of which 5, 7 million are in forced and bonded labour. 1, 8 million are in prostitution and 0,3 million in armed conflict. More than 110 million children of primary education age are not in school. The ongoing conflicts and wars around the globe has resulted in 2 million children killed; 4 - 5 million disabled; 12 million left homeless; more than 1 million orphaned or separated from their parents; and 10 million psychologically traumatized.

Structure and agency commonly combine to force children into work and commercial sex. Persistence of, and increasing impulses of poverty, inequalities and marginalization due to neo-liberal economic policies promoted by international monetary organizations, neo-imperialist wars and destruction, piece meal approaches to development and lack of political will to bring in structural, economic and political changes by the power elites, keep the rest of us (intellectuals and activists) in a state of helplessness when it comes to macro-solutions needed to create conditions in which children can live out their childhood in dignity.

\section{Acknowledgements}

I am grateful to Prof. Lennart Svensson and Dr. Glen Helmstad of Lund University, Sweden, without whose help I could not have written my Phil.lic which consolidated my interest in childhood and triggered off this article.

\section{REFERENCES}

[1] M. Meynert. Conceptualizations of Childhood, Pedagogy and Educational Research in the Postmodern - A Critical Interpretation, (Fil.lic dissertation), Department of Sociology, Division of Education, Faculty of Social Sciences, Lund University, Sweden, 2014.

[2] S. Kvale (ed). Issues of Validity in Qualitative Research, Studentlitteratur publishers, 1989.

[3] P. Aries. Centuries of Childhood, Penguin Books, (1962/1996).

[4] H. Cunnigham. The Invention of Childhood, BBS Books, 2006.

[5] D. Lancy. The Anthropology of Childhood, Cherubs, Chattel, Changelings, Utah State University, 2016.
[6] P. Aries. Centuries of Childhood, Penguin Books, (1962/1996).

[7] L. deMause (ed). The History of Childhood, Bellew, 1976.

[8] E. Shorter. The Making of the Modern Family, Fontana, 1975.

[9] L. deMause (ed). The History of Childhood Bellew, 1976.

[10] P. Aries. Centuries of Childhood, Penguin Books, (1962/1996).

[11] M. Meynert. Conceptualizations of Childhood, Pedagogy and Educational Research in the Postmodern - A Critical Interpretation, Cambridge Scholars Publishing, 2015.

[12] B. A. Hanawalt. Growing up in medieval London: The Experience of Childhood in History, Oxford University Press, 1993.

[13] E. West. Children on the Plains frontier in E West and P. Petrick (eds), Small Worlds, Lawrence KS: University of Kansas Press, 1992.

[14] L. Alston. "Children as Chattel” in E West and P. Petrick (eds), in Small Worlds, Lawrence KS: University of Kansas Press, 1992.

[15] D. Nasaw. Children of the city - At Work and at Play, Penguin Random House, 2012.

[16] L. Pollock. Forgotten Children - parent-child relations from 1500-1900, Cambridge University Press, 1983.

[17] S. Shahar, Childhood in the Middle Ages, Routledge, 1992.

[18] D: K: Wiggins. The play of slave children in the plantation communities of the old South, 1820-60, in Journal of Sport History, Vol. 7, No. 2 (Summer, 1980), University of Illinois Press, 1985.

[19] L. deMause (ed). The History of Childhood, Bellew, 1976.

[20] L. Pollock. Forgotten Children - parent-child relations from 1500-1900, Cambridge University Press, 1983.

[21] P. Aries. Centuries of Childhood, Penguin Books, (1962/1996).

[22] L. DeMause (ed). The History of Childhood Bellew, 1976.

[23] J. Clarke. "Children And Childhood.- Inter-Disciplinary Perspective: Histories Of Childhood", in Childhood Studies: An Introduction, (ed) Dominic Wyse, Wiley-Blackwell, 2004.

[24] P. S. Fass. (ed) The Routledge History of Childhood in the Western World, Routledge, 2015.

[25] P. Aries. Centuries of Childhood, Penguin Books, (1962/1996).

[26] L. Stone. The Family, Sex and Marriage in England, 1500-1800, Weidenfeld, 1977.

[27] M. Fleer, M. Hedegaard, J. Tudge (eds). Childhood Studies and the Impact of Globalization: Policies and Practices at Global and Local Levels, Routledge, 2009.

[28] H. Hendricks.. Children, Childhood and English Society, 1880-1990. Cambridge University Press, 1997.

[29] J .L. Kincheloe. The sign of the burger: McDonald's and the culture of power, Temple University Press, 2002. 
[30] J. Clarke. "Children And Childhood.- Inter-Disciplinary Perspective: Histories Of Childhood", in Childhood Studies: An Introduction, (ed) Dominic Wyse, Wiley-Blackwell, 2004.

[31] J. J. Rousseau. Emile, or On Education. Trans. Allan Bloom. New York: Basic Books, 1979.

[32] J. Clarke. "Children and Childhood - Inter- Disciplinary Perspective: Histories of Childhood", in Childhood Studies: An Introduction, (ed) Dominic Wyse, Wiley- Blackwell, 2004.

[33] P. S. Fass. (ed) The Routledge History of Childhood in the Western World, Routledge, 2015.

[34] J. Diamond. The World before Yesterday, Viking Press, 2012.

[35] J. Clarke. "Children and Childhood. Inter-Disciplinary Perspective: Histories of Childhood", in Childhood Studies: An Introduction, (ed) Dominic Wyse, Wiley-Blackwell, 2004.

[36] A. Khakshour, M.A. Abbasi, S. J. Sayedi, M. Saeidi, G. H. Khodaee, Child Labour, Facts in the Worldwide: A review Article, (Pages: 467-473), in the Int J Pediatr, Vol.3, N.1-2, Serial No.14, February 2015.

[37] J. Clarke. "Children And Childhood.- Inter-Disciplinary Perspective: Histories of Childhood", in Childhood Studies: An Introduction, (ed) Dominic Wyse, Wiley-Blackwell, 2004.

[38] H. Hendricks.. Children, Childhood and English Society, 1880-1990. Cambridge University Press, 1997

[39] B. Sandin. "The Century of the Child". On the Changed Meaning of Childhood in the Twentieth Century, 1995. Retrieved from http://www.diva-portal.org/smash/get/ diva2: 511663/FULLTEXT02.pdf (accessed 20170404).

[40] A. James, A. Prout, Allan. Constructing and Reconstructing Childhood -Contemporary Issues in the Sociological Study of Childhood, Cambridge: Polity Press, 2007.

[41] P. Aries. Centuries of Childhood, Penguin Books, 1992/1996.

[42] R. Freedman. Kids at Work: Lewis Hine and the Crusade against Child Labor, Clarion Books, 1998.

[43] A. Khakshour, M.A. Abbasi, S. J. Sayedi, M.. Saeidi, G. H. Khodaee (2015), Child Labour Facts in the Worldwide: A review Article, (Pages: 467-473), in the Int J Pediatr, Vol.3, N.1-2, Serial No.14, February 2015.

[44] M. Meynert. Conceptualizations of Childhood, Pedagogy and Educational Research in the Postmodern - A critical Interpretation, Cambridge Scholars Publishing, 2015.
[45] M. Ravallion. "How long will it take to lift one billion people out of poverty? The World Bank Research Observer 28, 2:139, 2013.

[46] World Bank World Bank (2015), World Bank Forecasts Global Poverty to Fall Below 10\% for First Time; Major Hurdles Remain in Goal to End Poverty by 2030. World Bank. IBRD. IDA. Retrieved from http://www.demos.org /blog/7/28/14/two-theories-poverty (accessed 20170408).

[47] S. Haymes, M. V. de Haymes, R. Miller (eds). The Routledge Handbook of Poverty in the United States, Routledge, 2015.

[48] P. Townsend. Poverty in the United Kingdom, Allen Lane and Penguin, 1979.

[49] M. Meynert. Conceptualizations of Childhood, Pedagogy and Educational Research in the Postmodern - A Critical Interpretation, Cambridge Scholars Publishing, 2015.

[50] N. Postman. The Disappearance of Childhood. New Random House, 1994.

[51] K. McDonnell. Honey, We Lost the Kids: Re- thinking Childhood in the Multimedia Age, Pluto Press, 2006.

[52] J .L. Kincheloe.. The sign of the burger: McDonald's and the culture of power, Temple University Press, 2002.

[53] D. Elkind. The Hurried Child: Growing Up Too Fast Too Soon, Perseus Publishing, 2001.

[54] Amnesty International -Convention on the Rights of the Child. Retrieved from http://www.amnestyusa.org/our-workissues/ children-s-rights/convention-on-the-rights-of-the-child-0 (accessed 20170405).

[55] M. Meynert. Conceptualizations of Childhood, Pedagogy and Educational Research in the Postmodern - A Critical Interpretation, Cambridge Scholars Publishing, 2015.

[56] K. Basu, Z. Tzannatos. The Global Child Labor Problem: What Do We Know and What Can We Do? THE WORLD BANK Economic Review, Vol 17, No: 1: 111-113. December 2003. Retrieved from http://citeseerx.ist.psu.edu/viewdoc/download?doi=10.1.1.10 24.498\&rep $=$ rep $1 \&$ type $=p d f($ accessed 200411).

[57] ILO (International Labour Organization. Every Child Counts: New Global Estimates on Child Labor. Geneva: International Labour Office, 2002. 